\title{
PERILAKU PICKY EATER DAN STATUS GIZI PADA ANAK TODDLER
}

\author{
Endah Puji Astuti', Ika Fitria Ayuningtyas ${ }^{2}$ \\ ${ }^{1,2}$ Prodi Kebidanan, Sekolah Tinggi Ilmu Kesahatan Jenderal Achmad Yani Yogyakarta, endahpujias7@gmail.com
}

\begin{tabular}{l} 
INFO ARTIKEL \\
\hline RiwayatArtikel: \\
Diterima: 03-01-2018 \\
Disetujui: $31-01-2018$ \\
\end{tabular}

\section{Kata Kunci:}

Anak Toddler, Status Gizi,

Picky Eater

\begin{abstract}
ABSTRAK
Abstrak: Anak toddler adalah anak usia 1-3 tahun, pada periode ini merupakan konsumen pasif, artinya anak menerima makanan dari apa yang disediakan ibunya. Anak usia toddler memiliki karakteristik tersendiri dalam berbagai ranah pertumbuhan dan perkembangannya. Kesulitan makan dan berlangsung lama sering dianggap biasa, sehingga akhirnya timbul komplikasi dan gangguan tumbuh kembang lainnya pada anak. Picky eating adalah salah satu masalah kesulitan makan yang umum dialami oleh $8 \%$ sampai $50 \%$ anak- anak. Tujuan penelitian adalah mengetahui gambaran perilaku picky eater pada anak toddler dan status gizi anak toddler di Gamping Kidul Ambarketawang Gamping Sleman Yogyakarta. Jenis penelitian ini merupakan diskriptif dengan metode cross sectional. Sampel penelitian ini adalah anak usia toddler yang mengikuti posyandu saat dilakukan penelitian yang diantarkan oleh orangtua. Data primer diambil dengan mengukur antropometri anak (berat badan/umur, tinggi badan, lingkar kepala, lingkar lengan atas) dan pegisian kuesioner oleh orang tua tentang perilaku makan orang tua dan anaknya. Hasil penelitian status gizi pada anak toddler di Gamping Kidul Ambarketawang Gamping Sleman Yogyakarta indeks massa tubuh BB/U katagori gizi baik 87,10\%, tinggi badan normal 83,87\%, lingkar kepala normal 90,32\% dan Lila normal $61,29 \%$. Perilaku picky eater pada anak toddler $74,19 \%$ tidak mengalami picky eater.
\end{abstract}

\begin{abstract}
Children toddler is a child aged 1-3 years, in this period is a passive consumer, meaning children receive food from what provided by his mother. Toddler-age children have their own characteristics in various spheres of growth and development. Difficulty eating and lasting is often considered normal, so that eventually arise complications and other growth disorders in children. Picky eating is one of the common eating difficulties experienced by $8 \%$ to $50 \%$ of children. The purpose of this research is to know the description of picky eater behavior in toddler children and nutritional status of toddler children in Gamping Kidul Ambarketawang Gamping Sleman Yogyakarta. The type of this research is descriptive quantitative with cross sectional method. The sample of this research is toddler age children who follow posyandu when conducted research delivered by parents. Primary data was taken by measuring the anthropometry of the child (weight / age, height, head circumference, upper arm circumference) and pegikuian questionnaire by parents about the eating behavior of parents and children. Result of research of nutritional status at toddler children in Gamping Kidul Ambarketawang Gamping Sleman Yogyakarta body mass index BB / U good nutrition category $87,10 \%$, normal height $83,87 \%$, normal head circumference $90,32 \%$ and normal Lila $61,29 \%$. Behavior picky eater on children toddler $74.19 \%$ did not experience picky eater.
\end{abstract}




\section{A. LATAR BELAKANG}

Anak usia toddler memiliki karakteristik tersendiri dalam berbagai ranah pertumbuhan dan perkembangannya. Pertumbuhan dan perkembangan biologis. Secara umum pertumbuhan baik dari segi berat maupun tinggi badab berjalan cukup stabil atau lambat. Anak usia toddler adalah anak usia 12-36 bulan (1-3 tahun) pada periode ini merupakan konsumen pasif, artinya anak menerima makanan dari apa yang disediakan ibunya (Uripi dalam Kusumawardani 2014). Pemberian makan pada anak memang sering menjadi masalah buat orangtua atau pengasuh anak. Faktor kesulitan makan pada anak yang sering dialami oleh sekitar $25 \%$ pada usia anak, jumlah akan meningkat sekitar 40-70\% pada anak yang lahir prematur atau dengan penyakit kronik. Hal ini pula yang sering membuat masalah tersendiri bagi orang tua.

Penelitian Joko Widodo di Jakarta tahun 2010 yang menyebutkan pada anak pra sekolah usia 2-3 tahun, didapatkan prevalensi kesulitan makan sebesar 33,6\%. Sebagian besar 79,2\% telah berlangsung lebih dari 3 bulan. Secara umum penyebab umum kesulitan makan pada bayi dibedakan dalam 3 faktor, diantaranya adalah hilangnya nafsu makan, gangguan fungsi saluran cerna, dan gangguan proses makan atau gangguan oral motor (Joko Widodo, 2012). Kesulitan makan dan berlangsung lama sering dianggap biasa, sehingga akhirnya timbul komplikasi dan gangguan tumbuh kembang lainnya pada anak. Salah satu keterlambatan penanganan masalah tersebut adalah pemberian vitamin tanpa mencari penyebabnya sehingga kesulitan makan tersebut terjadi berkepanjangan. Sering juga terjadi bahwa kesulitan makan tersebut dianggap dan diobati sebagai infeksi tuberkulosis yang belum tentu benar diderita anak. Penanganan kesulitan makan pada anak yang optimal diharapkan dapat mencegah komplikasi yang ditimbulkan, sehingga dapat meningkatkan kualitas anak Indonesia dalam menghadapi persaingan di era globalisasi mendatang khususnya. Tumbuh kembang dalam usia anak sangat menentukan kualitas seseorang bila sudah dewasa nantinya (Judarwanto, 2007).

Picky eater jika didiamkan dapat menyebabkan inadekuasi intake yang dapat berujung pada terjadinya gangguan pertumbuhan anak. Penelitian Saraswati (2012) menemukan bahwa anak yang mengalami picky eater lebih berisiko memiliki berat badan rendah, terutama pada anak usia balita, perilaku picky eater yang tidak diatasi sedini mungkin bisa menyebabkan anak terbiasa pilihpilih makanan dan bisa menyebabkan anak kekurangan asupan nutrisi sehingga dapat mempengaruhi status gizinya juga dapat menggambarkan suatu pola pembatasan makanan yang mungkin dapat berlanjut dan berperan dalam gangguan perilaku makanan saat dewasa.

Anak-anak seperti halnya orang dewasa memiliki makanan yang disukai ataupun yang tidak disukainya. Pada usia 2-3 tahun sekitar 20\% anak termasuk "picky eater". Anak biasanya tidak menyukai makanan yang terasa pahit maupun pedas dan masam. Terkadang anak tidak menyukai makanan karena warnanya tidak menarik, tetapi lebih sering karena makanan tersebut sulit untuk dikunyah. Anak-anak menyukai daging yang lembut dibandingkan daging yang keras, dan sayuran yang telah dimasak dibandingkan yang mentah.

Kesulitan makan pada anak berisiko tinggi menjadi malnutrisi seiring dengan bertambahnya usia. Hal ini dapat diidentifikasi dan ditindaklanjuti secara dini melalui pengukuran status gizi pada anak dengan kesulitan makan agar terhindar dari salah satu komplikasinya yaitu malnutrisi (Sjarif, 2011).

Masalah pola makan yang sering terjadi pada anak balita seperti picky eater dan penanganan yang salah terhadap perilaku picky eater oleh orang tua merupakan salah satu penyumbang peningkatan status gizi kurang maupun gizi buruk pada anak Indonesia (Kurniasih dalam Priyanti 2013). Pengasuh anak dengan karakteristik tertentu mempunyai dampak positif pada keadaan gizi anak.Ibu dari anak yang bergizi, merupakan ibu yang terampil mengurus anak, sabar, dan tampak dewasa dibandingkan ibu dari kelompok dengan anak bergizi rendah (LIPI dan UNICEF-Indonesia dalam Priyanah 2008). Orang tua banyak mempengaruhi perkembangan pola makan pada anak. Studi kuantitatif yang dipublikasikan tahun 1998 menguji pemilihan makan pada batita yang berhubungan dengan pemilihan makan anggota keluarganya (Skinner et al dalam Priyanah, 2008). Penelitian lain juga menunjukkan bahwa praktek pemberian makan yang salah dari orang tua atau karena kurang pengalaman dapat menyebabkan anak gagal tumbuh (Wiliams dalam Priyanah, 2008).

Pengukuran status gizi dapat didasarkan pada data antropometri, biokimia, serta riwayat diet yang kemudian berdasarkan data-data yang diperoleh dapat dinilai status gizinya. Status gizi dapat dianggap mewakili status kesehatan yang juga menggambarkan keseimbangan antara pemasukan dan kebutuhan nutrisi. Masalah makan merupakan faktor yang dapat mempengaruhi status gizi pada anak. Adanya ketidakseimbangan antara pemasukan dan kebutuhan nutrisi berisiko tinggi menjadi malnutrisi, terutama pada anak yang mengalami kesulitan makan. Kesulitan makan pada anak dapat disebabkan oleh berbagai macam keadaan, oleh karena itu status gizi pada setiap anak yang didiagnosa mengalami kesulitan makan 
juga bervariasi tergantung pada penyebabnya (Sjarif, 2011).

Berdasarkan studi pendahuluan yang telah dilakukan di Dukuh Gamping Kidul terdapat 10 anak usia 1-5 tahun mengalami masalah perilaku pilih-pilih makan yang disebut picky eater, dan 4 diantaranya balita mengalami gizi dibawah garis merah (BGM), sehingga penulis tertarik untuk meneliti status gizi, perilaku makan orangtua dan perilaku picky eater pada anak toddler di Gamping Kidul Ambarketawang Gamping Sleman Yogyakarta.

\section{B. METODE PENELITIAN}

Jenis penelitian yang digunakan adalah penelitian deskriptif dengan metode cross sectional.. Penelitian ini menggambarkan status gizi dan perilaku picky eater pada anak toddler. Penelitian ini dilakukan di Dukuh Gamping Kidul Ambarketawang, Gamping, Sleman, Yogyakarta yang dilaksanakan pada Bulan SeptemberNovember 2017. Teknik pengambilan sampel dalam penelitian ini adalah secara purposive sampling yaitu pengambilan sampel didasarkan pada suatu pertimbangan tertentu dengan syarat inklusi anak usia 1-3 tahun, hadir di posyandu pada sat penelitian dan bersedia menjadi responden penelitian. Jumlah sempel sebantak 30 responden. Alat atau instrumen yang digunakan adalah kuesioner, timbangan, pengukut tinggi badan, medline. Metode pengumpulan data pada penelitian ini adalah dengan mengumpulkan data primer yaitu memberikan kuesioner tentang pola makan dan perilaku pilih makanan atau picky eater pada anak, yang diberikan kepada orangtua yang mempunyai anak usia toddler serta menilai status gizi anak dengan mengukur berat badan (menghitung IMT yaitu BB/umur), panjang badan, lingkar kepala dan Lila.

\section{HASIL DAN PEMBAHASAN}

\section{Karakteristik Balita di Desa Ambar ketawang Yogyakarta Gamping Sleman}

TABEL 1

Karakteristik Balita di Desa Ambarketawang Gamping Sleman Yogyakarta

\begin{tabular}{lcc}
\hline \multicolumn{1}{c}{ Karakteristik balita } & F & P \\
\hline Jenis kelamin & & \\
Laki-laki & 19 & $61,29 \%$ \\
Perempuan & $\mathbf{1 2}$ & $38,71 \%$ \\
\hline Pendidikan anak usia dini & & \\
Ikut PAUD & 7 & $\mathbf{2 2 , 5 8 \%}$ \\
Tidak ikut PAUD & $\mathbf{2 4}$ & $77,42 \%$ \\
\hline Pemberian ASI & & \\
ASI eksklusif & $\mathbf{2 8}$ & $90,32 \%$ \\
Tidak ASI eksklusif & 3 & $9,68 \%$ \\
\hline
\end{tabular}

(Sumber: Data Primer 2017)
Berdasarkan Tabel 1 karakteristik balita sebagian besar jenis kelamin laki-laki yaitu 61,29\%, mengikuti tidak ikut PAUD 77,42\%, dan memberikan ASI eksklusif 90,32\%.

\section{Status Gizi Balita Di Dukuh Gamping Kidul Desa Ambarketawang Gamping Sleman Yogyakarta}

TABEL 2

Status Gizi Pada Balita Di Dukuh Gamping Kidul di Desa Ambarketawang Gamping Sleman Yogyakarta

\begin{tabular}{lcc}
\hline \multicolumn{1}{c}{ Status Gizi } & F & P \\
\hline IMT BB/U & & \\
Baik & 27 & $87,10 \%$ \\
Kurang & 2 & $6,45 \%$ \\
Buruk & 2 & $6,45 \%$ \\
\hline Total & 31 & $100 \%$ \\
\hline TB/U & & \\
Normal & 26 & $83,87 \%$ \\
Stuting & 5 & $16,13 \%$ \\
\hline Total & 31 & $100 \%$ \\
\hline LK/U & & \\
Normal & 28 & $90,32 \%$ \\
Tidak Normal & 3 & $9,68 \%$ \\
\hline Total & 31 & $100 \%$ \\
\hline Lila & & \\
Normal & 19 & $61,29 \%$ \\
KEK & 12 & $38,71 \%$ \\
\hline Sumber: Data Prim
\end{tabular}

(Sumber: Data Primer 2017)

Balita Tabel 2 sebagian besar memiliki indek massa tubuh baik 87,10\%, tinggi badan normal 83,87\%, lingkar kepala normal 90,32\% dan lila normal 61,29\%.

\section{Perilaku Makan Balita Di Dukuh Gamping Kidul Desa Ambarketawang Gamping Sleman Yogyakarta.}

TABEL 3

Perilaku Makan Balita Di Dukuh Gamping Kidul di Desa Ambarketawang Gamping Sleman Yogyakarta

\begin{tabular}{lcc}
\multicolumn{1}{c}{ Perilaku Makan } & F & P \\
\hline Picky eater & 6 & $19,35 \%$ \\
Tidak picky eater & 25 & $80,65 \%$ \\
\hline Total & 31 & $100 \%$ \\
\hline
\end{tabular}

(Sumber: Data Primer, 2017)

Berdasarkan Tabel 3 balita sebagian besar tidak mengalami masalah makan atau picky eater 74,19\%. Perilaku picky eater yang dialami balita dijelaskan dalam tabel berikut. 


\section{TABEL 4}

perilaku picky eater Balita Di Dukuh Gamping Kidul di Desa Ambarketawang Gamping Sleman Yogyakarta

\begin{tabular}{lllc}
\hline Picky eater & F & P \\
\hline a. Hanya ingin makan & 2 & $33,33 \%$ \\
makanan yang sukai & 2 & $33,33 \%$ \\
b. Menolak jika dikenalkan & 1 & $16,67 \%$ \\
jenis makanan baru & 1 & $16,67 \%$ \\
c. Menolak atau makan & & \\
& sedikit jenis makanan \\
& \\
tertentu sama sekali & \\
d. Menolak sama disukai & \\
makanan yang tidak dis & \\
\hline Total & 6 & $100 \%$ \\
\hline
\end{tabular}

(Sumber: Data Primer 2017)

\section{TEMUAN}

\section{Status gizi pada anak toddler di Gamping Kidul Ambarketawang Gamping Sleman Yogyakarta}

Status gizi menjadi indikator ketiga dalam menentukan derajat kesehatan anak. Status gizi yang baik dapat membantu proses pertumbuhan dan perkembangan anak untuk mencapai kematangan yang optimal. Gizi yang baik juga dapat memperbaiki ketahanan tubuh sehingga diharapkan tubuh akan bebas dari segala penyakit. Status gizi ini dapat membantu untuk mendeteksi lebih dini risiko terjadinya masalah kesehatan. Pemantauan status gizi dapat digunakan sebagai bentuk antisipasi dalam merencanakan perbaikan status kesehatan anak.

Penilaian status gizi terbagi atas penilaian secara langsung dan penilaian secara tidak langsung. Adapun penilaian secara langsung dengan metode antropometri sedangkan penilaian status gizi secara tidak langsung dengan metode survei konsumsi makanan. Anak usia toddler di Gamping Kidul Ambarketawang Gamping Sleman Yogyakarta sebagian besar dilihat dari indeks massa tubuh $\mathrm{BB} / \mathrm{U}$ katagori gizi baik 87,10\%, tinggi badan normal $83,87 \%$, lingkar kepala normal 90,32\% dan Lila normal $61,29 \%$. Masih ditemukan beberapa balita yang mengalami status gizi kurang dan buruk, stunting, KEK dan lingkar kepala yang kurang sesuai dengan usia.

Makanan akan mempengaruhi pertumbuhan serta perkembangan fisik dan mental balita, oleh karena itu makanan yang diberikan harus memenuhi kebutuhan gizi balita. Balita dalam proses pertumbuhan dan perkembangannya ditentukan oleh makanan yang dimakan sehari-hari, untuk tumbuh optimal membutuhkan asupan makanan yang baik yaitu beragam, jumlah yang cukup, bergizi dan seimbang (Depkes RI dalam Santi 2016).

\section{Perilaku picky eater pada anak usia toddler di Gamping Kidul Ambarketawang Gamping Sleman Yogyakarta}

Menurut Ikatan Dokter Anak Indonesia (2014) picky eater berarti anak mau mengonsumsi berbagai jenis makanan baik yang sudah maupun yang belum dikenalnya tapi menolak mengonsumsi dalam jumlah yang cukup. Selain jumlah yang tidak cukup, picky eater pun berhubungan dengan rasa dan tekstur makanan. Walaupun pilih-pilih makanan, picky eater masih mau mengonsumsi minimal satu macam makanan dari setiap kelompok karbohidrat, protein, sayur/buah dan susu.

Balita usia 1-3 tahun di Dukuh gamping kidul 25,81\% mengalami picky eater. masalah pilih makan yang dialami diantaranya hanya ingin makan makanan yang sukai, menolak jika dikenalkan jenis makanan baru, menolak atau makan sedikit jenis makanan tertentu, dan menolak sama sekali makanan yang tidak disukai.

Anak usia 1-3 tahun merupakan konsumen pasif, artinya anak menerima makanan dari apa yang disediakan ibunya. Laju pertumbuhan masa batita lebih besar dari masa usia prasekolah sehingga diperlukan jumlah makanan yang relatif besar. Namun perut yang masih lebih kecil menyebabkan jumlah makanan yang mampu diterimanya dalam sekali makan lebih kecil dari anak yang usianya lebih besar. Oleh karena itu, pola makan yang diberikan adalah porsi kecil dengan frekuensi sering (Uripi Kusumawardani 2014).

Penyajian makanan untuk balita diperlukan kreatifitas ibu agar makanan terlihat menarik sehingga dapat menimbulkan selera makan anak balita. Penyajian makanan yang akan diberikan kepada anak balita harus memperhatikan porsi atau takaran konsumsi makan serta frekuensi makan yang dianjurkan dalam sehari. Pemberian makanan dibagi menjadi tiga waktu makan yaitu pagi hari pada pukul 07.00-08.00, siang hari pada pukul 12.00-13.00, dan malam hari pada pukul 18.0019.00. Pemberian makanan selingan yaitu antara dua waktu makan yaitu pukul 10.0011.00 dan pukul 16.00-17.00 (Depkes RI dalam Santi 2016). Ibu balita di Dusun Gamping Kidul Ambarketawang Gamping Sleman Yogyakarta, sebagian besar menjadwalkan waktu makan dan hanya beberapa yang menunggu waktu anak lapar atau meminta makan saja. 


\section{E. SIMPULAN DAN SARAN}

Status gizi pada anak toddler di Gamping Kidul Ambarketawang Gamping Sleman Yogyakarta indeks massa tubuh $\mathrm{BB} / \mathrm{U}$ katagori gizi baik $87,10 \%$, tinggi badan normal $83,87 \%$, lingkar kepala normal 90,32\% dan Lila normal 61,29\%. Perilaku picky eater pada anak usia toddler di Gamping Kidul Ambarketawang Gamping Sleman Yogyakarta 74,19\% tidak mengalami picky eater. Saran bagi ibu menyiapkan makanan untuk anggota keluarga dengan gizi seimbang dan beragam, agar anak dapat menkonsumsi makanan yang lebih bervariasi dengan tampilan yang menarik anak untuk makan. Bagi kader posyandu melakukan pemantau lebih intensif terhadap balita yang mengalami masalah status gizi.

\section{UCAPAN TERIMA KASIH}

Tim penulis mengucapkan terima kasih kepada PPPM Sekolah Tinggi Ilmu Kesehatan Jenderal Achmad Yani Yogyakarta yang telah mendanai penelitian ini.

\section{DAFTAR RUJUKAN}

[1] Kusumawardhani, N. 2013. Determinan 'Picky Eater 9 pilih-Pilih Makanan Pada Anak Usia 1-3 Tahun. Jurnal Majapahit Vol 5 No. 2 November 2013.

[2] Priyanah. 2008. Gambaran karakteristik anak picky eater yang pernah memeriksakan diri ke klinik picky eater jakarta tahun 2008. Skripsi. FKM UI, Depok

[3] Santi, Eka. 2016. Peningkatan Kemampuan Ibu Melakukan Stimulasi Perkembangan Makan Toddler Picky Eate. Jurnal Dunia Keperawatan Volume 2 Nomer 2 September 2016, 71-81

[4] Saraswati, D.,P.,M. Gambaran Perilaku Picky Eater dan Faktor yang MelatarBelakanginya Pada Siswa PAUD Kasih Ananda Bekasi Tahun 2012. Skripsi.Depok :Fakultas Kesehatan Masyarakat Universitas Indonesia, 2012.

[5] Sjarif DR. Draft algoritma pendekatan masalah makan. Dalam: Proposed algorithm for classification and management of feeding difficulties in Indonesia. Simposium, Manado: Abbot Nutrition; 2011 